\title{
latrogenic venous air embolism from central femoral vein catheterisation
}

\author{
Leena Jalota, Madan Raj Aryal, Shashank Jain
}

Department of Internal Medicine, The Reading Health System, Wyomissing, Pennsylvania, USA

\section{Correspondence to} Dr Leena Jalota, leena.jalota@gmail.com
To cite: Jalota L, Aryal MR, Jain S. BMJ Case Rep Published online: [please include Day Month Year] doi:10.1136/bcr-2013008965

\section{DESCRIPTION}

A woman in her late 40s was brought to the emergency room with abdominal pain and was found to be septic and in hypoxemic respiratory failure. As part of the initial resuscitation a right-sided femoral catheter was placed by the emergency room physician and the patient moved to the intensive care unit. A CT scan of the chest, abdomen and pelvis obtained for initial evaluation revealed air within the distal inferior vena cava (IVC) likely related to placement of the right inguinal catheter (figures 1 and 2 ). Also noted was a small amount of air in the left external iliac vein, right common iliac vein and small amount of soft tissue emphysema was seen within the right ventricular wall. Patient was immediately placed into left lateral decubitus position (known as the Durant's maneuver) and kept on $100 \%$ oxygen for $48 \mathrm{~h}$. Repeat imaging after $48 \mathrm{~h}$ showed resolved gas in the IVC and at other sites.

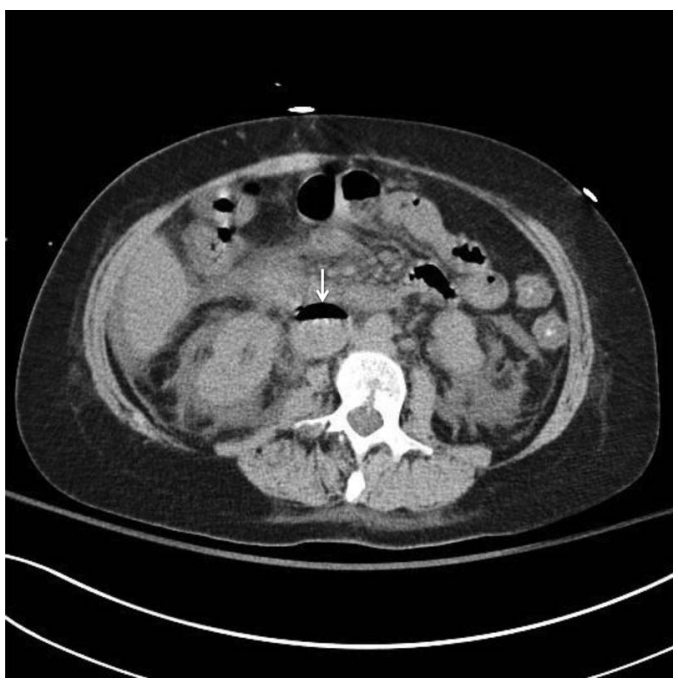

Figure 1 Contrast-enhanced CT of the abdomen showing air in the distal inferior vena cava (white arrow).

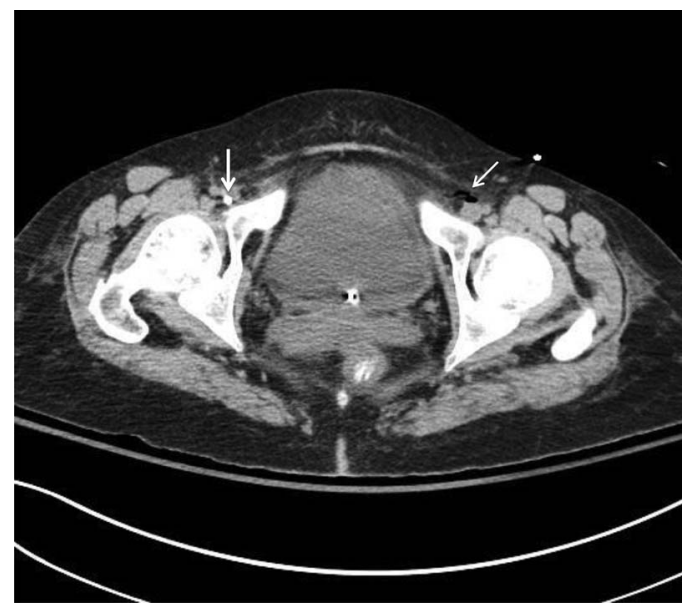

Figure 2 Contrast-enhanced CT of the abdomen showing central venous catheter tip within the right external iliac vein (thick arrow) as well as air in the left external iliac vein (thin arrow).

Venous air embolism (VAE) is an uncommon, unrecognised but potentially catastrophic event that occurs as a consequence of entry of air into the vasculature. It is commonly related to iatrogenic causes including central venous catheterisations. $^{1}$ Once encountered immediate management should be initiated with an aim to avoid air trapping and decrease the size of air embolus. If left untreated the mortality and morbidity can be high. This case serves as an important reminder to physicians obtaining central venous access to take appropriate precautions in order to reduce the potential for VAE.

Competing interests None.

Patient consent Obtained.

Provenance and peer review Not commissioned; externally peer reviewed.

\section{REFERENCE}

1 Vesely TM. Air embolism during insertion of central venous cathetors. J Vasc Interv Radiol 2001;12:1291-5.

Copyright 2013 BMJ Publishing Group. All rights reserved. For permission to reuse any of this content visit http://group.bmj.com/group/rights-licensing/permissions.

BMJ Case Report Fellows may re-use this article for personal use and teaching without any further permission.

Become a Fellow of BMJ Case Reports today and you can:

- Submit as many cases as you like

- Enjoy fast sympathetic peer review and rapid publication of accepted articles

- Access all the published articles

- Re-use any of the published material for personal use and teaching without further permission

For information on Institutional Fellowships contact consortiasales@bmjgroup.com

Visit casereports.bmj.com for more articles like this and to become a Fellow 